\title{
ETNOMATEMATIKA: EKSPLORASI ALAT MUSIK TRADISIONAL KHAS BATAK TOBA
}

\author{
${ }^{1}$ Natalia Sitanggang \\ ${ }^{1}$ Pendidikan Matematika, Fakultas Keguruan dan Ilmu Pendidikan, Universitas Muhammadiyah \\ Sukabumi
}

\begin{abstract}
Abstrak
Tujuan dilakukannya penelitian adalah untuk mengeksplorasi hubungan antara matematika dan budaya, khususnya dalam alat musik tradisioan khas Batak Toba. Penelitian ini menggunakan penelitian kualitatif dengan jenis kepustakaan. Hasil yang diperoleh dari penelitian ini menunjukkan bahwa dalam alat musik tradisional khas Batak Toba memiliki berbagai konsep matematika seperti konsep bangun datar dan konsep bangu ruang. Oleh karena itu, alat musik tradisional khas Batak Toba dapat digunakan sebgai sumber belajar matematika pada pembelajaran sekolah dasar dan sekolah menengah pertama. Selain itu dapat mengubah paradigma siswa dan masyarakat bahwa matematika memiliki hubungan dengan kehidupan sehari-hari.
\end{abstract}

Kata kunci : etnomatematika, alat musik tradisional, bangun datar \& bangun ruang

matematika selalu dianggap sebagai pelajaran yang sangat sulit. Sehingga guru memiliki peran yang sangat penting dalam proses belajar mengajar. Guru harus mampu mengelola kelas salah satunya dengan cara pendekatan budaya yang disebut etnomatematika. Hubungan antara matematika dan budaya dapat disebut dengan etnomatematika. Etnomatematika adalah suatu ilmu matematika yang mempelajari tentang budaya (Aini et al., 2018; Rohmaini et al., 2020). Budaya dijadikan sebagai sumber belajar matematika yang dapat digunakan disekolah untuk mempermudah pembelajaran di kelas. Salah satu budaya yang dapat dijadikan sebagai sumber belajar matematika adalah alat musik tradisional khas sumatra utara. Di Provinsi Sumatra Utara banyak dijumpai suku dan etnis. Suku bangsa batak yang terdiri dari etnis Pak-pak Dairi, Mandailing, Simalungun, Karo dan Angkola pesisir Tapanuli Tengah. Setiap suku memiliki keunikan masing-masing dan berbeda satu dengan yang lainnya. Namun pada kesempatan ini akan membahas alat musik tradisional yang dimiliki oleh masyarakat Batak Toba. Jenis alat musik tradisional khas Batak Toba bermacammacam dan memiliki bentuk dan ukuran yang berbeda-beda. Ukuran dan bentuk pada alat musik tradisioanl khas Batak Toba dapat dijadikan sumber belajar matematika.

\section{METODE}

Tujuan penelitian ini untuk mengeksploarasi hubungan antara matematika dan 
budaya khusunya pada alat musik tradisioanl khas Batak Toba. Metode penelitian yang digunakan dalam penelitian ini adalah metode studi pustaka. Teknik pengumpulan data dari buku, artikel, literatur, laporan dan catatan yang ada hubungannya dengan masalah yang dipecahkan.

\section{HASIL DAN PEMBAHASAN}

Berdasarkan hasil pengumpulan data dapat diketahui bentuk dan ukuran dari alat musik tradisioanl khas Batak Toba memiliki konsepkonsep matematika. Beberapa alat musik tradisional Batak Toba sebagai berikut.

1. Sarune Bolon

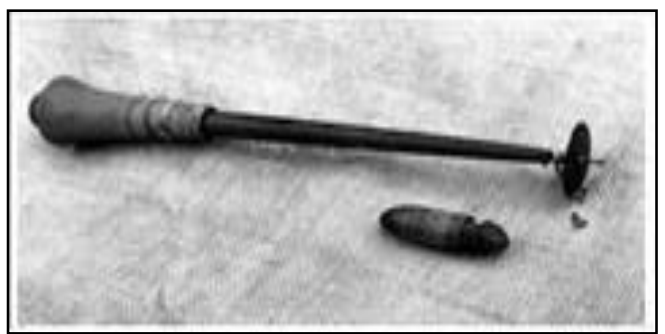

Gambar 1. Sarune Bolon

Salah satu alat musik tradisional suku Batak Toba adalah Sarune Bolon yang terbuat dari kayu dan tanduk kerbau. Sarune Bolon mempunyai suatu alat bantu sebagai sumber suara yang biasa disebut dengan ipit-ipit (Double Reed) yang terbuat dari kayu arang. Alat musik ini dimainkan dengan cara ditiup. Teknik meniup Sarune Bolon dengan sekali tarikan napas. Pada acara Gondang Batak, Sarune Bolon selalu dimainkan pertama kali sebagai pembawa melodi dan pembawa lagu.

2. Pangora

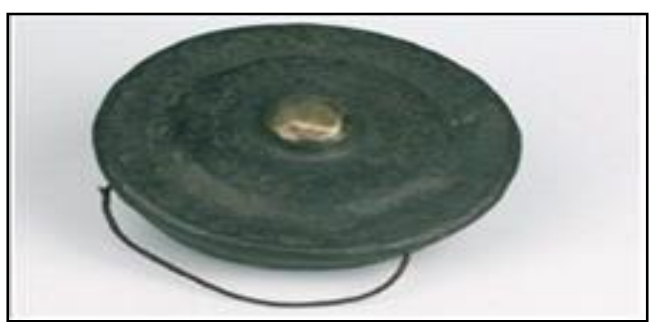

Gambar 2. Pangora

Alat musik Pangora sejenis dengan gong Jawa karena bentuk sama. Namun berbeda Pangora berbeda dengan gong dari bunyi yang di hasilkan. Cara menggunakan Pangora dengan dipukul menggunakan stik.
3. Garatung

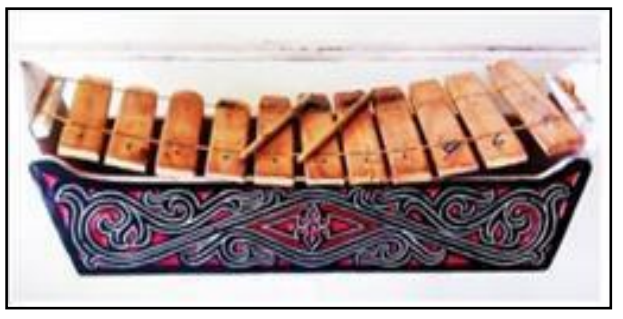

Gambar 3. Garatung

Garatung adalah alat musik Batak Toba yang terbuat dari kayu dengan lima bilah nada. Biasanya pada permainan musik batak Garatung sebagai pembawa melodi dan pembawa ritem variable pada lagu-lagu tertentu. Garatung dimanainkan dengan memukul 5 bilah nada yang disebut Mamalu. Garatung terdiri dari 7 wilahan yang berbentuk seperti balok yang digantungkan di atas kotak. Alat musik ini dimainkan dengan menggunakan stik kemudian dipukul. Stik pada tangan kiri sebagai pembawa ritme dan pembawa melodi sedangkan stik pada tangan kanan memukul tangkai garating dalam memainkan sebuah lagu.

4. Taganing

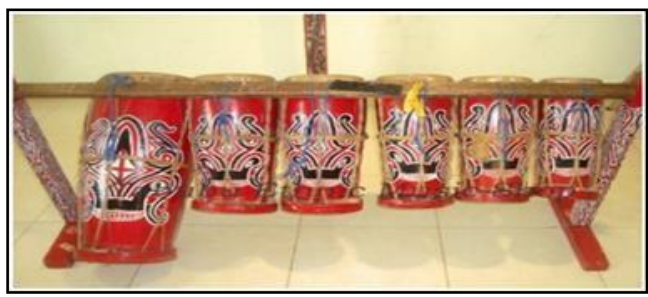

Gambar 4. Taganing

Salah satu alat musik tradisional Batak Toba yang paling terkenal adalah Taganing. Alat musik ini terbuat dari kulit kerbau dan kayu yang dibentuk seperti tabung. Taganing dimainkan dengan cara dipukul menggunakan stik yang disebut Palupali. Taganing terdiri dari 5 gendang dengan ukuran yang berbeda-beda dan bunyi atau nada berbeda. Tagaing biasanya dimainkan oleh satu sampai 2 orang pemain. Dalam sebuah permaianan musik, Taganing dan Sarune Bolon akan berpadu menghasilkan melodi yang berfungsi sebgai pemberi aba-aba. 
5. Hapetan (Hasapi)

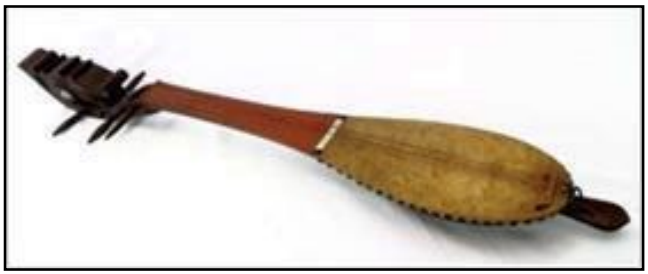

Gambar 5. Hapetan (Hasapi)

Hapetan adalah alat musik tradisioanl berasal dari Sumatra Utara sejenis kecapi Hapetan dimainkan dengan cara dipetik. Hapetan sering juga disebut dengan Hasapi.

6. Gondang

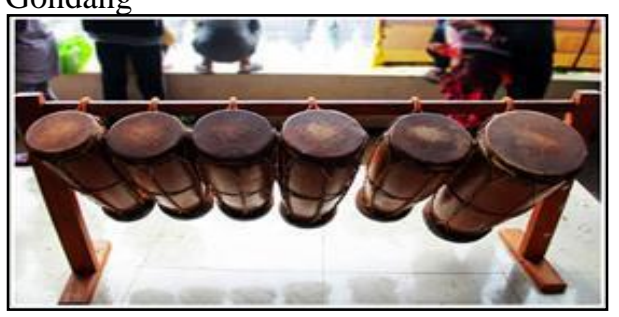

Gambar 6. Gondang

Gondang (Gordang) adalah alat musik Batak Toba yang mirip dengan Taganing tepai ukurannya lebih besar terbuat dari kayu dan kulit kerbau. Gondang dimainkan dengan cara dipukul dengan tangan dan bisa juga menggunakan stik.

7. Ihutan

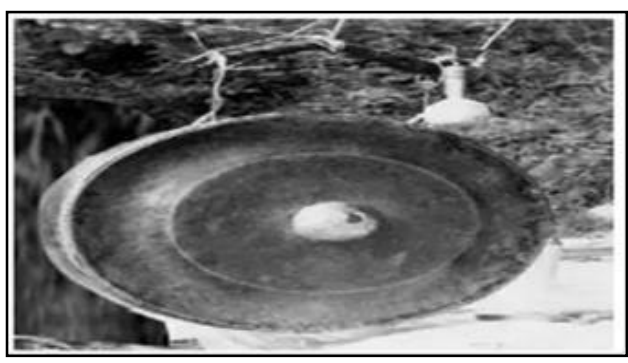

Gambar 7. Ihutan

Ihutan adalah alat musik tradisioanl Batak Toba mirip dengan Panggora sejening gong. Yang membedakan Ihutan dengan gong lain dilihat dari ukuran, bunyi dan cara permainannya. alat musik ini dimainkan dengna stik yang terbuat dari kayu yang dibungkus kain atau karet. Ihutan dimainkan dengan ritme konstan dan bersahut-sahutan.

8. Sarune Bulu

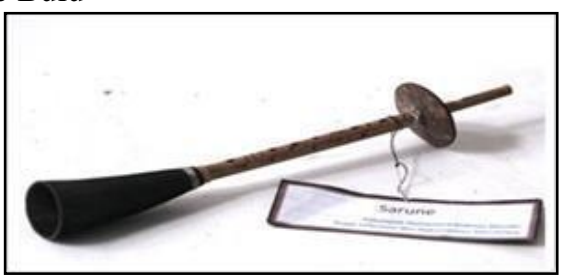

Gambar 8. Sarune Bulu

Sarune Bulu adalah alat musik Batak Toba terbuat dari bambu yang dilubangi di setiap ujungnya. Badan dari Sarune Bulu diberikan 5 lubang dengan ukuran yang berbeda. Alat musik ini dimainkan dengan cara ditiup.

9. Sulim

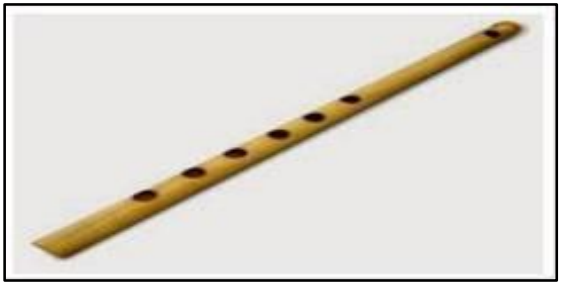

Gambar 9. Sulim

Sulim adalah alat musik Batak Toba yang sering disebut dengan Seruling. Sulim terbuat dari bambu dengan badan bambu diberikan lubang. Pada umumnya Sulim terdapat 6 lubang yang jaraknya tidak diukur secara sembarangan. Bedanya Sulim dengan jenis seruling lain adalah dari bunyi yang dihasilkan yang terus bergetar. Hal tersebut terjadi karena Sulim memiliki satu lubang yang kecil dan ditutp dengan membran berbahan plastik.

Alat musik tradisonal khas batak toba terdapat 9 jenis alat musik tradisional Batak Toba yaitu, Sarune Bolon, Panggora, Garatung, Taganing, Hapetan, Gondang, Ihutan, Sarune Bulu dan Sulim. Dari hasil analisis terhadap bentukbentuk alat musik tersebut diketahui bahwa alat musik tradisional Batak Toba tersebut memiliki bentuk-bentuk geometri berupa bangun datar dan bangun ruang. Konsep bagun datar pada alat musik Batak Toba adalah sebagai berikut.

1. Lingkaran

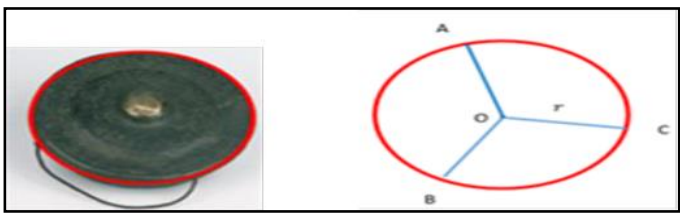

Gambar 10. pemodelan geometri Pangora

Gambar diatas adalah pemodelan secara geometri Pangora. Berdasarkan hasil analisis bentuk pangora terdapat konsep geometri yaitu lingkaran. Lingkaran adalah garis lengkung yang kedua ujungnya saling bertemu dan semua titik yang terdapat pada garis lengkung mempunyai jarak yang sama terhadap titik pusat. Pada gambar di atas, dapat disimpulkan bahwa lingkaran mempunyai sifat-sifat yaitu : 
lingkaran tidak mempunyai sudut, lingkaran hanya mempunyai 1 sisi, mempunyai simetri lipat dan simetri putar dengan jumlah yang tak terbatas dan jarak antara titik-titik garis lengkung terhadap titik pusat mempunyai jarak sama. Titik $O$ disebut titik pusat, sedangkan titik A, B, dan C, yang mempunyai jarak sama ke titik $\mathrm{O}$ disebut jari-jari (r).

Rumus Lingkaran

Diameter $\quad=d=2 r$

Keliling $=2 \pi r$

Luas $\quad=\frac{22}{7} \cdot \pi r^{2}$

Ket:

$r=$ jari-jari

2. Segitiga

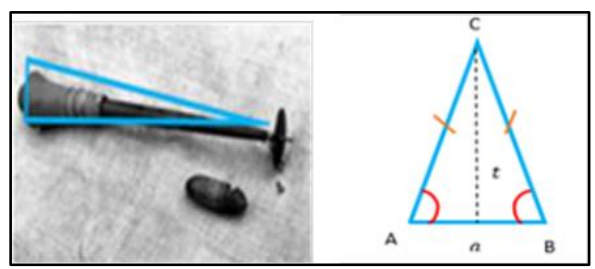

Gambar 11. Pemodelan geometri Sarune Bolon

Gambar diatas adalah pemodelan secara geometri dari Sarune Bolon. Berdasarkan hasil analisis bentuk Sarune Bolon terdapat konsep geometri yaitu segitiga sama kaki.segitiga sama kaki adalah segitiga yang hanya mempunyai 2 sisi yang sama panjang. Pada gambar diatas, dapat disimpulkan bahwa segitiga mempunyai sifat-sifat yakni: 2 sisi yang sama panjang sebagai kaki segitiga $(\mathrm{AC}=\mathrm{AB})$, mempunyai 2 sudut yang sama besar yaitu sudut yang berhadapan dan sama panjang, mempunyai 1 sumbu simetri dan 3 simetri putar.

Rumus segitiga

Keliling segitiga $=a+b+c$

Luas segitiga $\quad=\frac{1}{2} \cdot a \cdot t$

Ket:

$a=$ alas segitiga

$t=$ tinggi segitiga

3. Persegi Panjang

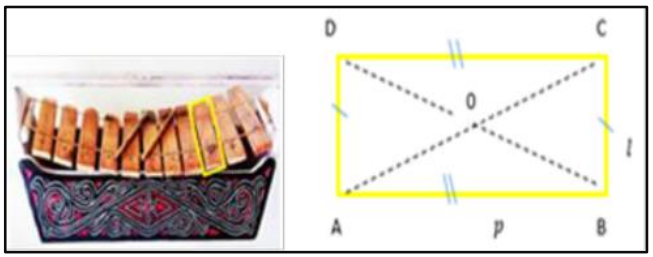

Gambar 12. Pemodelan geometri Garatung
Gambar diatas adalah pemodelan secara geometri Garatung. Berdasarkan hasil bentuk dari Garatung terdapat konsep geometri yaitu persegi panjang. Pada gambar diatas, dapat disimpulkan bahwa persegi panjang mempunyai soifat-sifat yakni: persegi panjang mempunyai sisi yang berhadapa sama panjang, kedua diagonal sama panjang $(\mathrm{OA}=\mathrm{OB}=\mathrm{OC}=\mathrm{OD})$, keempat sudutnya siku siku $(\angle \mathrm{OA}=\angle \mathrm{OB}=$ $\angle O C=\angle O D=90^{\circ}$ ), persegi panjang mempunyai 2 buah simetri lipat dan 2 buah simetri putar.

Rumus persegi panjang

Keliling persegi panjang: $\quad=2 \times(p+l)$

Luas persegi panjang: $\quad=p \times l$

Ket:

$p=$ panjang

$l=$ lebar

4. Trapesium

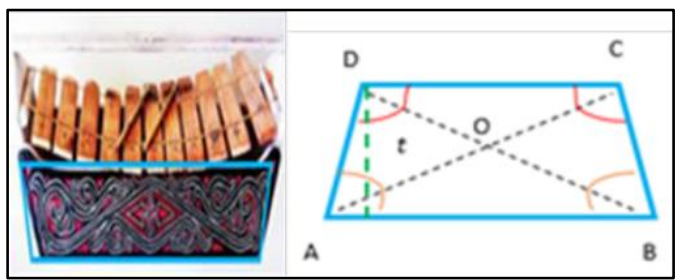

Gambar 13. Pemodelan geometri Garatung

Gambar diatas adalah pemodelan geometri dari Garatung. Berdasarkan hasil analisis bentuk dari garatung terdapat konsep geometri yaitu trapesium. Pada gambar diatas, dapat disimpulkan bahwa Garatung mempunyai sifatsifat yakni: trapesium sepasang sisi yang sejajar, jumlah sudut berdekatan diantara sisi sejajar adalah $180^{\circ}$, dan mempunyai 2 diagonal sama panjang.

Rumus trapesium

Keliling trapesium: $=A+B+C+D$

Luas trapesium: $\quad=\frac{1}{2}(a+b)$

Ternyata alat musik tradisioanl khas Batak tidak hanya dapat di modelkan ke bentuk bangun datar melainkan dapat juga dalam bentuk bangun ruang. Konsep bangun ruang pada alat musik tradisional Batak Toba adalah sebagai berikut.

1. Tabung

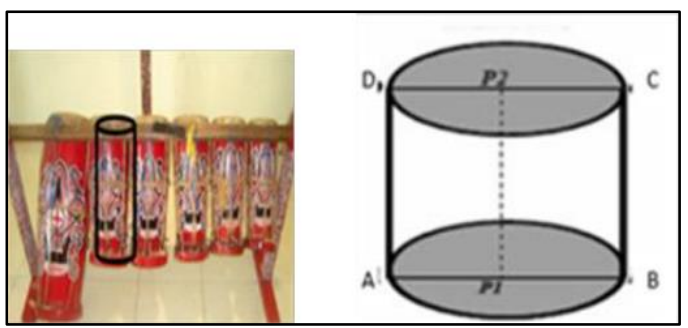


Gambar 14. Pemodelan geometri Taganing

Gambar diatas adalah pemodelan secara geometri dari Taganing. Berdasarkan hasil analisis bentuk dari Taganing terdapat konsep geometri yaitu tabung. Pada gambar diatas, dapat disimpulkan bahwa tabung mempunyai sifat-sifat yakni: tabung mempunyai 3 sisi yaitu 2 sisi alas (sisi alas berbentuk lingkaran dengan pusat P1 dan sisi atas berpusat P2) dan 1 sisi selimut (sisi lengkung), sisi alas dan sisi atas adalah lingkaran yang kongruen, tabung mempunyai diameter $\mathrm{AB}$ dan diameter atas $\mathrm{CD}$, jari jari alas ( $\mathrm{r}$ ) lingkaran $\mathrm{P} 1 \mathrm{~A}$ dan $\mathrm{P} 1 \mathrm{~B}$ dan jari -jari atas $\mathrm{P} 2 \mathrm{~A}$ dan $\mathrm{P} 2 \mathrm{~B}$, tinggi tabung $\mathrm{P} 2 \mathrm{P} 1$, DA, dan CB.

Rumus Tabung

Luas Alas

$=\frac{22}{7} \cdot \pi r^{2}$

Volume Tabung

$=\pi r^{2} t$

Keliling lingkaran alas /tutup $=2 \pi r$

Luas Selimut

$=2 \pi r t$

Luas Permukaan Tabung

$=2 \pi r(r+t)$

2. Kerucut

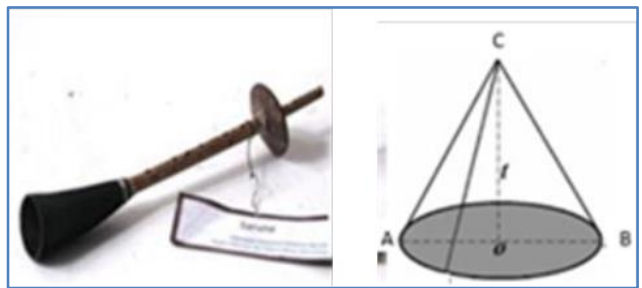

Gambar 15. Pemodelan geometri Sarune Bulu

Gambar diatas adalah pemodelan secara geometri dari Sarune Bolon. Berdasarkan hasil analisis bentuk dari sarune bolon menyerupai kerucut. Gambar pemodelan Sarune Bulu terdapat konsep geometri yaitu kerucut. Dari gambar dapat disimpulkan bahwa kerucut mempunyai sifat-sifat sebagai yakni: kerucut mempunyai 2 sisi yaitu sisi alas dan sisi selimut, mempunyai alas berbentuk lingkaran, garis OA dan OB sebagai jari jari alas (r) sedangkan garis $\mathrm{AB}$ disebut diameter, mempunyai selimut kerucut, jarak dari titik puncak terhadap bidang alas (garis OC) disebut tinggi kerucut $(\mathrm{t})$ mempunyai titik puncak $\mathrm{C}$, garis pelukis (s) yaitu garis pada selimut kerucut yang ditarik dari titk puncak ke titik pada lingkaran, mempunyai 1 rusuk lengkung.
Rumus kerucut

Luas Permukaan Kerucut $=$ L. Alas + L.Selimut

$$
\begin{aligned}
& =\pi r^{2}+\pi r s \\
& =\pi r(r+s) \\
& =\pi r^{2}+\pi s
\end{aligned}
$$

Volume Kerucut

\section{KESIMPULAN}

Budaya dapat dijadikan sumber belajar matematika yang dikenal dengan istilah etnomatematika. Alat musik tradisional khas Batak merupakan salah satu contoh budaya yang dapat dijadikan sumber belajar matematika. Kita dapat menemukan konsep geometri pada alat musik khas Batak berupa bangun datar dan bangun ruang. Guru dapat memanfaatkan bentuk-bentuk bangun datar dan bangun ruang yang ada pada alat musik sebagai sumber belajar yang konkret dan inovatif, serta dapat membantu meningkatkan proses berpikir siswa. Sehingga pembelajaran akan lebih bermakna. Dibawah ini beberapa soal terkait dengan konsep geometri pada alat musik tradisional Batak Toba

1. Diketahui sebuah Pangora benbentuk lingkaran mempunyai diameter sebesar $30 \mathrm{~cm}$. tentukan Luas dan Keliling Pangora yang ada?

2. Sebuah Garatung berbentuk persegi panjang mempunyai panjang $10 \mathrm{~cm}$ dan lebar $5 \mathrm{~cm}$. tentukan:

a. Luas Garatung

b. Keliling Garatung

\section{DAFTAR PUSTAKA}

Sylviyani.2017. Etnomatematika: aplikasi bangun datar segiempat pada candi Muaro Jambi. Aksioma Vol 8, No. 2.

Hikmawati, Sitti Raehana. 2019. Etnomatematika: makanan tradisional Bugis sebagai sumber.

Agustiana, E., Putra, F. G., \& Farida, F. (2018). Penerapan model pembelajaran Auditory, Intellectually, Repetition (AIR) dengan pendekatan lesson study terhadap kemampuan pemecahan masalah matematis peserta didik. Desimal: Jurnal Matematika, 1(1), 1-6.

Aini, E. P., Masykur, R., \& Komarudin, K. (2018). Handout Matematika berbantuan Etnomatematika Berbasis Budaya Lokal. Desimal: Jurnal Matematika, 1(1), 73-79. https://doi.org/10.24042/djm.v1i1.1950

Akbar, P., Hamid, A., Bernard, M., \& Sugandi, A. I. (2018). Analisis kemampuan pemecahan 
masalah dan disposisi matematik siswa kelas xi sma putra juang dalam materi peluang. Jurnal Cendekia: Jurnal Pendidikan Matematika, 2(1), 144-153.

Komarudin, K., Sujadi, I., \& Kusmayadi, T. A. (2014). Proses Berpikir Kreatif Siswa SMP Dalam Pengajuan Masalah Matematikaditinjau Dari Gaya Kognitif Siswa (Studi Kasus Pada Siswa Kelas Viii-h SMP Negeri 1 Sukoharjo Tahun Pelajaran 2012/2013). Jurnal Pembelajaran Matematika, 2(1).

Komarudin, K., \& Thahir, A. (2019). Bahan Ajar Berbasis Mathematical Comic: Dampak Terhadap Peningkatan Pemahaman Matematis Peserta Didik. Jurnal Pendidikan Matematika RAFA, 5(2), 98110.

Rodiawati, H., \& Komarudin, K. (2018). Pengembangan E-Learning Melalui Modul Interaktif Berbasis Learning Content Development System. Jurnal Tatsqif, 16(2), 172-185.

Rohmaini, L., Netriwati, N., Komarudin, K., Nendra, F., \& Qiftiyah, M. (2020). Pengembangan Modul Pembelajaran Matematika Berbasis Etnomatematika Berbantuan Wingeom Berdasarkan Langkah Borg And Gall. Teorema: Teori Dan Riset Matematika, 5(2), 176-186.

Maryanti, Wira Pratiwi. 2018. Etnomatematika: eksplorasi dalam tarian tradisional pada pembukaan asian games 2018.

Firda, Sunardi, Lioni, Didik, Erfan. Etnomatematika pada alat music Tradisional banyuwangisebagai Bahan ajar siswa.

Sinambela, P. N. 2017. Kurikulum 2013 dan Implementasinya dalam Pembelajaran. Generasi Kampus, Vol. 6(2).

Depdiknas. (2003). Undang-undang republic Indonesia nomor 20 tahun 2003 tentang sistem pendidikan nasional. Jakarta: Depdiknas.

https://www.silontong.com/2018/05/06/alat-musiktradisional-batak-toba/

Sofia, Abdul, Hasratuddin. 2018. Eksplorasi etnomatematika pada alat musik gordang sambilan._Vol 1 no. 2 